\title{
Corrosion Inhibition of Mild Steel in Simulated Seawater by Nymphae Pubscens Leaf Extracts (NLE)
}

\author{
Hart Kalada.G ${ }^{1}$, Orubite-Okorosaye. $\mathbf{K}^{\mathbf{2}}$, James Abodsede. $\mathbf{O}^{3}$ \\ ${ }^{123}$ Department of Pure and Industrial Chemistry, P.M.B 5323, University of Port Harcourt, Rivers State, Nigeria \\ *Corresponding Author: Hart Kalada.G, Department of Pure and Industrial Chemistry, P.M.B 5323, \\ University of Port Harcourt, Rivers State, Nigeria
}

\begin{abstract}
The corrosion inhibitory behaviour of Nymphae Pubescens (water lily) leaf extract (NLE) was studied using weight loss technique. NLE concentrations of $1 \%, 2 \%, 3 \%, 4 \%$ and $5 \% \mathrm{v} / \mathrm{v}$ were used at temperatures 303, 313, 323 and 333K. Functional groups present in NLE, probably responsible for the inhibition were analyzed using FTIR. Inhibition efficiency was found to increase with increasing inhibitor concentration. Temperature affected the corrosion inhibition of mild steel by NLE as corrosion rate increased with increase in temperature and a subsequent decrease in the inhibition efficiency. The highest inhibition efficiency of $85.91 \%$ was obtained at $303 \mathrm{~K}$ with inhibitor concentration $5 \% \mathrm{v} / \mathrm{v}$ and the least inhibition efficiency of $24.51 \%$ at $333 \mathrm{~K}$ with inhibitor concentration $1 \% \mathrm{v} / \mathrm{v}$. Even at $313 \mathrm{~K}$ the highest concentration of NLE $(5 \% \mathrm{v} / \mathrm{v})$ gave inhibition efficiency of $77.36 \%$. The surface morphology from scan electron microscopy examination (SEM) confirms this trend. The adsorption of the inhibitor was more suited with the Temkin adsorption isotherm and thermodynamic data calculated are suggestive of physical adsorption of the inhibitor molecules on the mild steel surface.
\end{abstract}

Keywords: Sea water; Mild Steel; Nymphae Pubescens; Weight loss method; Corrosion rate, inhibition efficiency.

\section{INTRODUCTION}

Corrosion is the gradual destruction of materials by chemical reaction with their environment. In the most common use of the word, this means electrochemical oxidation of metal in reaction with an oxidant such as oxygen (Olawale, et al., 2016). Corrosion is a major problem in desalination plants as well as other industrial applications. In parts of the world with short supply of fresh water, there is an increasing use of sea water for fresh water production (Bardal.E, 2004). Most metal structures used in sea water (ships, oil platforms, piers, pipelines, etc.) are traditionally made of mild low-carbon and low alloy steels as well as copper based alloys. The salt content in the water causes both corrosion and abrasion in piping, tanks and process equipment. Protecting these valuable assets from the effects of exposure to seawater is a critical challenge for corrosion engineers in these regions.

Over the years, there have been reports on the corrosion of mild steel and its alloys in sea water environments (Malik et al, 1999, Melchers and Jeffery, 2005, Moller et al, 2006 and Aramide, 2009). The use of inhibitors is one of the most practical methods for protecting metallic corrosion, especially in hostile environment like seawater (Bakirhan et al, 2016). Plant extracts are a rich source of naturally synthesized chemical compounds, readily available low-cost and eco-friendly, and can be obtained through simple extraction processes with low cost as well as biodegradable (Eletre, 2007). Although many synthetic compounds show good corrosion inhibition ability, the search for more non toxic environmental friendly inhibitors are the focus now in metallic corrosion prevention. Literature records many plant extracts as effective corrosion inhibitors for iron or steel as well as copper and its alloys in aggressive corrosion media (Orubite and Oforka 2004, Abiola et., al 2007, Nnabuk 2009, Kalada and James 2011, Rajendran and Karthikeyan, 2012, Hamdy and El-Gendy, 2013, , Bammou et al, .2014) . Some of these plants are common aquatic weeds that have found use as corrosion inhibitors. Nymphae Pubscens (water lily) is an aquatic weed that grows in fresh water environment of Bonny Island. The plant is a native to the temperate and tropical parts of the world. Most species of water lilies have rounded variously notched, waxy-coated leaves on long stalks that contain many air spaces and float in quiet freshwater habitats (Encyclopedia Britannica, 2017). From the 
photochemical investigation of NLE it is worthy to note that the leaves of this aquatic weed contains hetro-atoms $(\mathrm{N}, \mathrm{S}$ and $\mathrm{O})$ and the availability of $\pi$ electrons in the aromatic system which are inherent in its complex mixture of glycosides, saponins, alkaloids, terpenes, tannins, phenolic substances and flavonoids (Khaled, 2008) . Not much use of it is made by the locals both for domestic or other purposes.

Table1. Phytochemical components of Nymphae Pubescens leaf extract

\begin{tabular}{|l|l|}
\hline Substances & Presence \\
\hline Saponins & ++ \\
\hline Tannins & +++ \\
\hline Flavonoid & - \\
\hline Cardiac Glycosides & + \\
\hline Alkaloids & +++ \\
\hline Anthroquinones & + \\
\hline Steroids & - \\
\hline Triterpenoids & - \\
\hline
\end{tabular}

$+++=$ highly present,$++=$ moderately present, $-=$ absent or presence in negligible quantity.

In this present work, corrosion inhibition of mild steel in seawater by Nymphae Pubescens (water lily) leaf extract was carried out using the weight loss method.

\section{EXPERIMENTAL}

\subsection{Material Preparation}

Mild steel sheets where obtained from the Science/Engineering Workshop, University of Port Harcourt. Each sheet was $1 \mathrm{~mm}$ in thickness and was mechanically press-cut into rectangular coupon size of $4 \mathrm{~mm}$ by $3 \mathrm{~mm}$. The coupons were polished with emery paper (600 grade), washed with deionized water, degreased with acetone, dried and weighed before experiments. The chemical composition of mild steel used is given below as follows:

Table2. Shows percentage composition of mild steel used for this research

\begin{tabular}{|c|c|c|c|c|c|c|}
\hline $\mathrm{C}$ & $\mathrm{Si}$ & $\mathrm{Mn}$ & $\mathrm{P}$ & $\mathrm{S}$ & $\mathrm{Ni}$ & $\mathrm{Fe}$ \\
\hline 0.28 & 0.22 & 0.73 & 0.015 & 0.006 & 0.007 & Remainder \\
\hline
\end{tabular}

\subsection{Preparation of Simulated Seawater}

Simulated seawater was used for this research rather than natural seawater in order to minimize the biological effects as well as provide a reproducible solution of known composition. The formula of Axelrod Glen S. (2005) was employed in this preparation.

Table2. Formula for $35.00 \%$ artificial seawater

\begin{tabular}{|l|c|}
\hline SALT & Concentration $(\mathbf{m g} / \mathbf{l})$ \\
\hline Sodium chloride $(\mathrm{NaCl})$ & 55 \\
\hline Sodium sulfate $\left(\mathrm{Na}_{2} \mathrm{SO}_{4}\right)$ & 10 \\
\hline Potassium chloride $(\mathrm{KCl})$ & 4 \\
\hline Sodium bicarbonate $\left(\mathrm{NaHCO}_{3}\right)$ & 1 \\
\hline Boric acid $\left(\mathrm{H}_{3} \mathrm{BO}_{3}\right)$ & 0.010 \\
\hline Magnesium chloride $\left(\mathrm{MgCl}_{2} \cdot 6 \mathrm{H}_{2} \mathrm{O}\right)$ & 32 \\
\hline Calcium chloride $\left(\mathrm{CaCl}_{2} \cdot 2 \mathrm{H}_{2} \mathrm{O}\right)$ & 4 \\
\hline
\end{tabular}

Source: Axelrod Glen S. (2005)

\subsection{Preparation of Plant Extracts}

Nymphae Pubescens leaves were plucked from a waterlogged area in Bonny Local Government area of Rivers State and identified at the University of Port Harcourt, Herbarium. Leaves extract of Nymphae Pubescens was prepared as described by Olamide et al., (2016).

\subsection{Weight Loss Measurement}

Mild steel coupons were immersed in five beakers containing various concentrations of the corrosion inhibitor and a sixth beaker without the inhibitor which was used as the control. For the experiment at 
$303 \mathrm{~K}$, the coupons were retrieved after 24 hours. They were thoroughly cleaned and washed with distilled water, degreased with acetone and weighed with an electronic balance. At elevated temperatures, the coupons were retrieved after six hours. The same process of weighing was applied. The difference between the present and previous weights were computed and recorded as the weight loss. The inhibition efficiency (I.E \%) was calculated using the following equation :

$I E \%=\frac{w-w i}{w} \times 100$

Where $\mathrm{w}$ and $\mathrm{w}_{\mathrm{i}}$ are weight loss of steel coupons in the absence and presence of NLE respectively.

The corrosion rate (C.R) in millimeter per year $\left(\mathrm{mmp}^{-1}\right)$ was computed using the relation: C. $R=\frac{\mathrm{KW}}{\mathrm{DAT}}$

Where $\mathrm{W}$ is the weight loss resulting from the difference in initial and final specimen weights (mg), A is the coupon surface area $\left(\mathrm{mm}^{2}\right)$, D represents the materials density $(\mathrm{mg} / \mathrm{cm} 3), \mathrm{K}$ is the Rate Constant (87.6) and $\mathrm{T}$ is the time of exposure (hours).

\subsection{Fourier Transform Infrared (FT-IR) Spectroscopy}

The functional groups present in NLE and the film formed on the metal surface were determined using the Cary-630 Agilent Fourier transform infra-red spectrophotometer. The analysis was carried out by scanning the sample through a wave number range of 650 to $4000 \mathrm{~cm}^{-1}$.

\subsection{Surface Morphology}

A scanning electron microscope (SEM) model JSM-5600 LV, was used to analyze the morphology of mild steel surface without and with inhibitor added. One piece of mild steel coupon was immersed in seawater solution while the second coupon was immersed in a solution of seawater and 5\%v/v of NLE for 24 hours. The coupons were rinsed dried, and subjected to SEM examination.

\section{RESULT AND DISCUSSIONS}

\subsection{Weight Loss Measurement}

Table3. Calculated values of corrosion rate $\left(m m p y^{-1}\right)$ and inhibition efficiency (I.E \%) for Mild Steel corrosion in seawater in the absence and presence of various concentrations of NLE at different temperatures

\begin{tabular}{|c|c|c|c|c|c|c|c|c|}
\hline \multirow{2}{*}{$\begin{array}{l}\text { Inhibitor } \\
\text { Concentration } \\
\text { (v/v\%) }\end{array}$} & \multicolumn{4}{|c|}{ Corrosion rate $\left(\mathrm{mmp}^{-1}\right) \times \mathbf{1 0}^{3}$} & \multicolumn{4}{|c|}{ Inhibition Efficiency (I.E \%) } \\
\hline & $303 \mathrm{~K}$ & $313 \mathrm{~K}$ & $323 \mathrm{~K}$ & $333 \mathrm{~K}$ & $303 \mathrm{~K}$ & $313 \mathrm{~K}$ & $323 \mathrm{~K}$ & $333 \mathrm{~K}$ \\
\hline 0 (blank) & 0.34 & 0.37 & 0.41 & 0.45 & - & - & - & - \\
\hline 1 & 0.31 & 0.34 & 0.38 & 0.41 & 30.71 & 28.09 & 24.8 & 24.51 \\
\hline 2 & 0.24 & 0.28 & 0.32 & 0.37 & 33.64 & 30.13 & 29.56 & 27.04 \\
\hline 3 & 0.19 & 0.24 & 0.28 & 0.32 & 54.3 & 51.7 & 50.56 & 48.74 \\
\hline 4 & 0.13 & 0.18 & 0.23 & 0.28 & 69.2 & 66.43 & 66.06 & 61.68 \\
\hline 5 & 0.07 & 0.12 & 0.18 & 0.24 & 85.91 & 84.05 & 79 & 77.36 \\
\hline
\end{tabular}

\subsection{The Effect of Addition of NLE on the Weight Loss of Mild Steel Coupons in Sea Water}

Inhibition efficiency IE (\%) and corrosion rate (CR) obtained from weight loss measurements at different concentrations of inhibitor at temperatures $303-333 \mathrm{~K}$ are summarized in Table 4 . It is evident that the extract inhibits the corrosion of mild steel, at all concentrations used $(1 \%-5 \% \mathrm{v} / \mathrm{v})$. Table 4 also reveals that mild steel coupons were protected to an extent in sea water. The values of corrosion rate obtained for the blank (no inhibitor) was more than when inhibitor was added to the corrosive media. Even at the lowest inhibitor concentration of $1 \% \mathrm{v} / \mathrm{v}$ corrosion rate $\left(0.31 \mathrm{mmpy}^{-1}\right)$ obtained was lower than the blank $\left(0.34 \mathrm{mmp}^{-1}\right)$ at $303 \mathrm{~K}$.

This trend has been reported by several researchers confirming the effectiveness of plant extracts as corrosion inhibitors (James and Akaranta. 2009, Orubite and Oforka 2004).

\subsection{Effect of Inhibition on Corrosion Rate}

Fig.1 below shows the effect of inhibitor concentration on the corrosion rate. As inhibitor concentration increased a corresponding decrease in the corrosion rate occurred. The lowest corrosion 


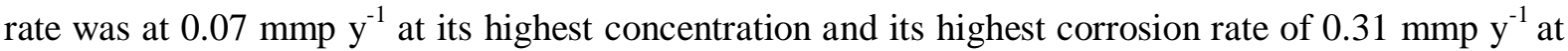
its lowest concentration. The effect of concentration on chemical reaction is an established fact in chemistry. Increase in concentration means more reactant molecules available for a chemical reaction. From the photochemical investigation of NLE, it is worthy to note that the leaves of this aquatic weed contains hetero atoms ( $\mathrm{N}$ and $\mathrm{O}$ ) and availability of $\pi$ electrons in the aromatic system which are inherent in its complex mixture of glycosides, saponins, alkaloids, terpenes, tannins, phenolic substances and flavonoids (Khaled,2008). Therefore increase in concentration means more of these heteroatoms adsorbed on the surface of the metal and subsequent decrease of corrosion rate. This is in agreement with findings from other works of Subir and Ishita, 2016 and Al-Otaibi et-al, 2012.

\subsection{Effect of Inhibitor Concentration and Adsorption Mechanism}

Inhibition efficiency plots are to show the effectiveness of an inhibitor in metal protection. This was done for NLE and presented in Figure 2. Inhibition efficiency as observed from the plot, increased with increased inhibitor concentration. The observed inhibition action of the NLE could be attributed to the adsorption of its components on the mild steel surface. They form layer of adsorbed molecules which isolates the metal surface from the aggressive medium leading to a decrease in the corrosion rate and hence a corresponding increase in its inhibition efficiency (James et al., 2009). Plots of surface coverage $(\Theta)$ expressed the extent of coverage of inhibitor molecules on metal surface. Table 5 below shows surface coverage data obtained for NLE molecules on mild steel coupons immersed in sea water. As inhibitor concentration increased more NLE molecules are available to cover mild steel's surface thus forming a barrier between sea water and the mild steel coupons and subsequent protection of the mild steel coupons. Studies by Hamdy.A and Nour Sh. El-Gendy, (2013) and Aisha Al-Moubaraki et.al., 2015 are in agreement with these findings. It can also be deduced from table 5 that the activation energies $\left(\mathrm{E}_{\mathrm{a}}\right)$ increase in the inhibited system as the concentration increases. The calculated values of $E_{a}$ ranges from $0.27-1.32 \mathrm{KJmol}^{-1}$ is less than the threshold value $\left(40 \mathrm{KJmol}^{-1}\right)$. Such behavior coupled with the increased inhibition efficiency is evident of physical adsorption mechanism as seen in figure 4 below.

Table5. Calculated values of Average Surface Coverage ( $\theta$ ), Activation Energy and Heat of Adsorption for Mild Steel corrosion in seawater in the absence and presence of various concentrations of Nymphae Pubescens leaf extracts at different temperatures using weight loss method.

\begin{tabular}{|c|c|c|c|c|c|c|}
\hline \multirow{2}{*}{$\begin{array}{l}\text { Inhibitor } \\
\text { Concentration } \\
(\mathrm{v} / \mathrm{v} \%)\end{array}$} & \multicolumn{4}{|c|}{ Average Surface Coverage $(\theta)$} & \multirow{2}{*}{$\begin{array}{c}\text { Activation Energy } \\
\left(\mathbf{E}_{\mathrm{a}}\right) \\
\left(\mathrm{kJmol}^{-\mathbf{1}}\right) \\
\end{array}$} & \multirow{2}{*}{$\begin{array}{c}\text { Heat of Adsorption } \\
\left(Q_{a d s}\right) \\
\left(\mathbf{k J m o l}^{-\mathbf{1}}\right) \\
\end{array}$} \\
\hline & $303 \mathrm{~K}$ & $313 \mathrm{~K}$ & $323 \mathrm{~K}$ & $333 \mathrm{~K}$ & & \\
\hline BLANK & - & - & - & - & 0.27 & - \\
\hline 1 & 0.31 & 0.28 & 0.25 & 0.25 & 0.22 & -16.574 \\
\hline 2 & 0.34 & 0.3 & 0.3 & 0.48 & -0.02 & -15.293 \\
\hline 3 & 0.54 & 0.52 & 0.51 & 0.49 & 0.30 & -7.1104 \\
\hline 4 & 0.69 & 0.66 & 0.66 & 0.62 & 0.09 & -1.9297 \\
\hline 5 & 0.86 & 0.84 & 0.79 & 0.77 & 1.32 & 3.56975 \\
\hline
\end{tabular}

Another thermodynamic parameter which further describes the adsorption mechanism is the heat of adsorption, $Q_{a d s}$. It is connected to the surface coverage $(\theta)$ through the relation:

$Q_{\text {ads }}=2.303 R\left[\left\{\log \left\{\theta_{2} / 1-\theta_{2}\right\}-\log \left\{\theta_{1} / 1-\theta_{1}\right\}\right]\right.$

Where, $\theta_{1}$ and $\theta_{2}$ are values on the degree of surface coverage at temperatures $T_{1}$ and $T_{2}$ respectively. The calculated values of $Q_{a d s}$ in table 5 show trend of a progressive move from negativity to positivity as the concentration of the inhibitor increases as well as an increase in the inhibition efficiency with temperature.

\subsection{Effect of Temperature on Corrosion Rate}

Fig. 3 represents the effect of temperature on the corrosion rate. This is also in line with other works (Oloruntoba, 2013 and Adams et-al, 2015) where the corrosion rate of mild steel in sea water increased as temperature increased. The lowest corrosion rate was observed at $303 \mathrm{~K}\left(0.07 \mathrm{mmp} \mathrm{y}^{-1}\right)$ and highest $\left(0.41 \mathrm{mmp}^{-1}\right)$ at $333 \mathrm{~K}$. Many metals are used in environments where temperatures differ from room temperature. This is the basis for studying the effect of temperature on the inhibitor efficiency.

The effect of temperature on the corrosion rate of mild steel in seawater with and without the NLE corrosion inhibitor was tested by the weight loss method over a temperature range from 303 to $333 \mathrm{k}$. 
The corresponding data are shown in table 5 above. Also from a close inspection of figure 3 , it is clearly seen that the effect of increasing temperature leads to an increase in the corrosion rate with and without NLE albeit to a lesser rate with NLE.

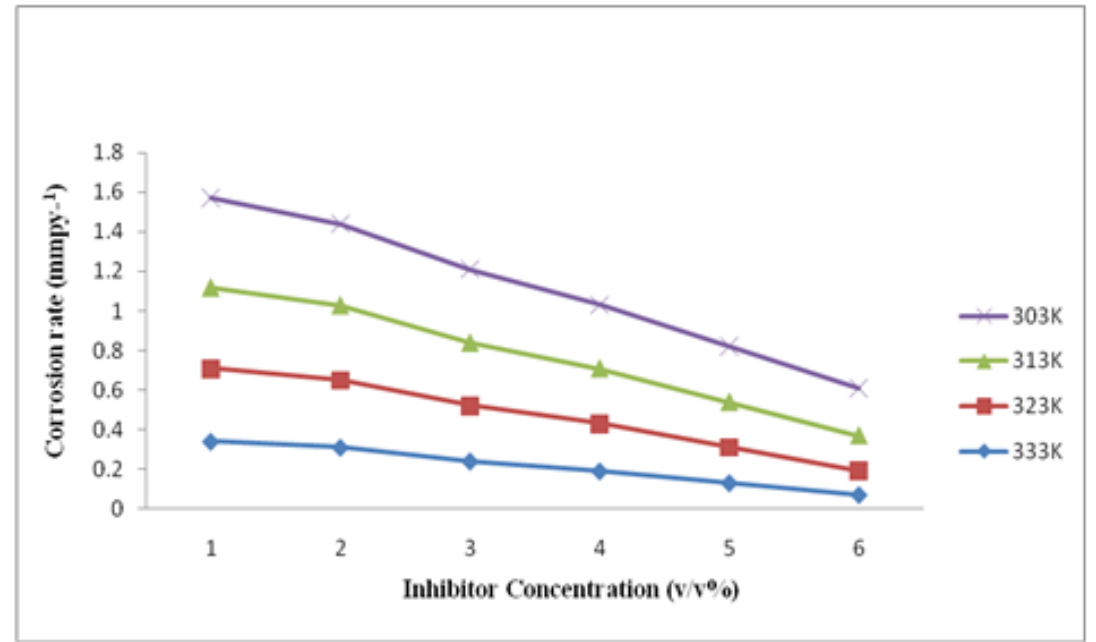

Fig1. Average Corrosion rate (mmp y-1) for Mild steel corrosion in seawatr in the absence and presenc of various concentrations of Nymphae pubescens leaf extracts at different temperatures

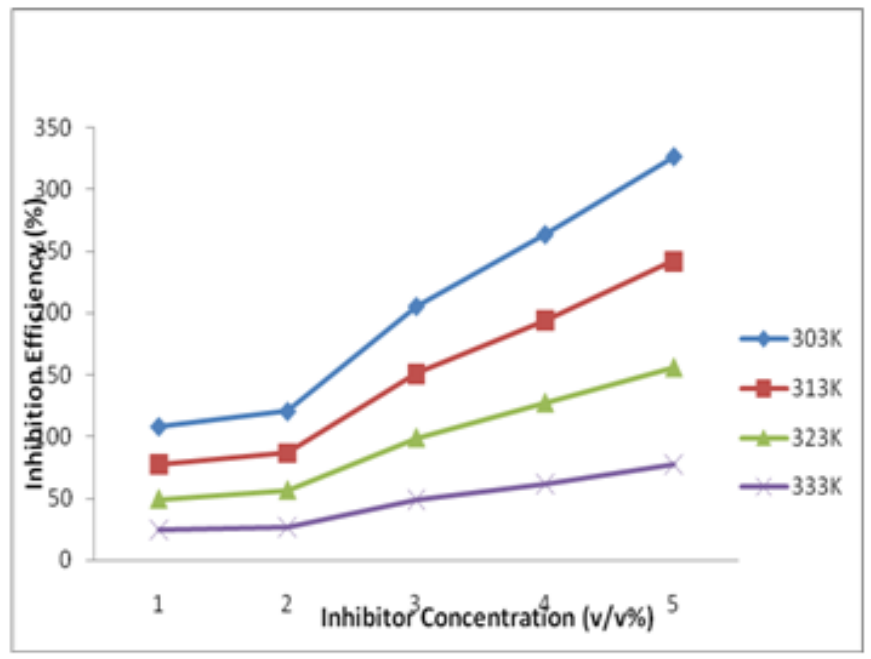

Fig2. Average inhibition efficiency (I.E\%) for mild steel in seawater in the presence of various concenntrations of Nymphae pubescens extracts at different temperatures

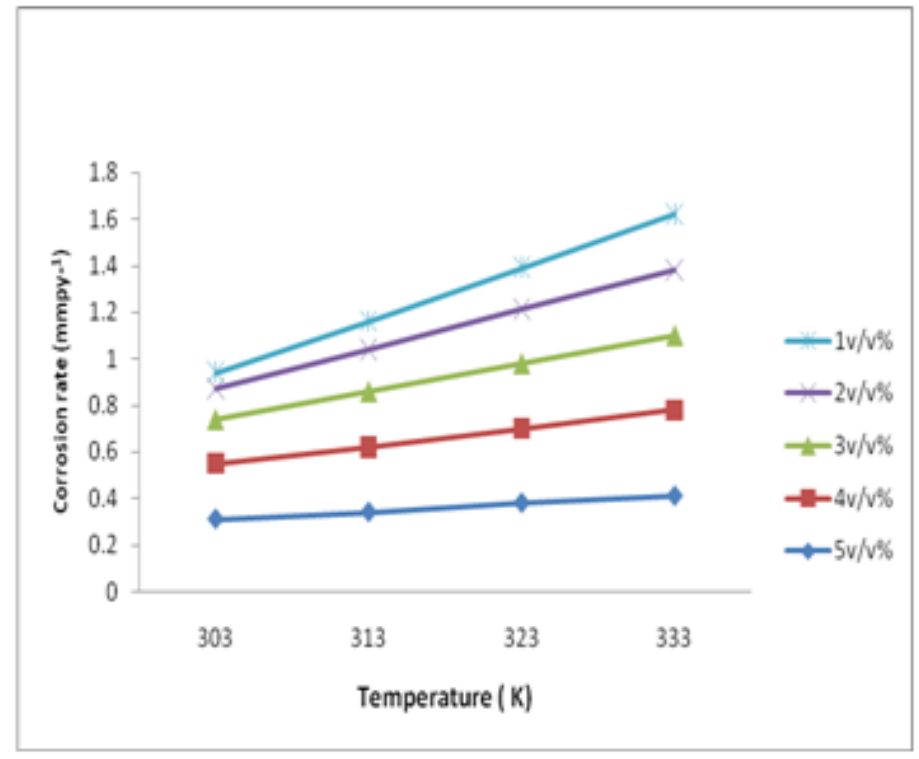

Fig3. Effect of temperature on the corrosion rate of Mild Steel in seawater using NLE 


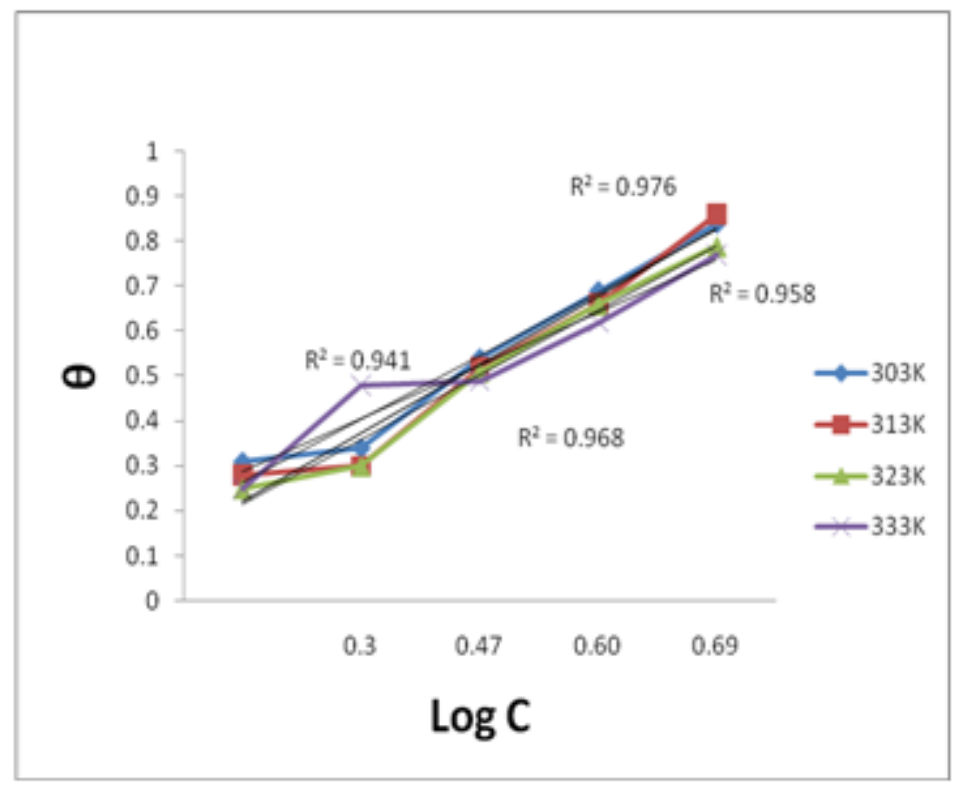

Fig4. Temkim Adsorption Isotherm for corrosion of mild steel in seawater

The effect of temperature on the inhibition efficiency is shown in Fig 2. The inhibition efficiency for the temperatures studied follows the trend $85.91>84.05>79>77.36 \%(303,313,323$ and $333 \mathrm{~K})$ respectively for the inhibitor concentration of $5 \% \mathrm{v} / \mathrm{v}$. It was generally observed that inhibition efficiency increase with increasing inhibitor concentration but decrease with increasing temperature, indicating an increased rate of dissolution of mild steel coupons in sea water and a partial desorption of the temporary protective film as temperature increases. This further suggests a physisorption mechanism of the inhibitor molecules on the mild steel surface, which is in line with the works of Kalada Hart and A.O. James (2014). The extract showed some reasonable efficiency even at higher temperature. At the highest temperature of $333 \mathrm{~K}$ an inhibition efficiency of $77.36 \%$ was recorded when $5 \% \mathrm{v} / \mathrm{v}$ extract concentration was used. Most inhibition efficiency record lower percentage at such high temperature (Nnanna et-al., 2014).

\subsection{Adsorption Isotherm}

Basic information on the interaction between the inhibitors and the metal surface can be provided by the adsorption isotherm. Using the values of the surface coverage, different adsorption isotherms can be used to deal with experimental data. Of all the adsorption isotherms tested the Temkim adsorption gave the best interpretation of interaction between the inhibitors and the metal surface as can be seen in fig. 4 above. It is worthy to note that $\mathrm{R}^{2}$ values were close to unity at both high and low temperatures investigated.

\subsection{Analysis of Protective Film}

The adsorptive protective film was further confirmed by FT-IR spectra of plant extract and mild steel surface immersed in seawater. The main constituents of NLE are alkaloids, saponins and tannins. These major constituents (hetero atoms) are responsible for the formation of a blanket on the metallic surface. The FT-IR spectrum of the NLE extract is shown in the fig. 5 below.

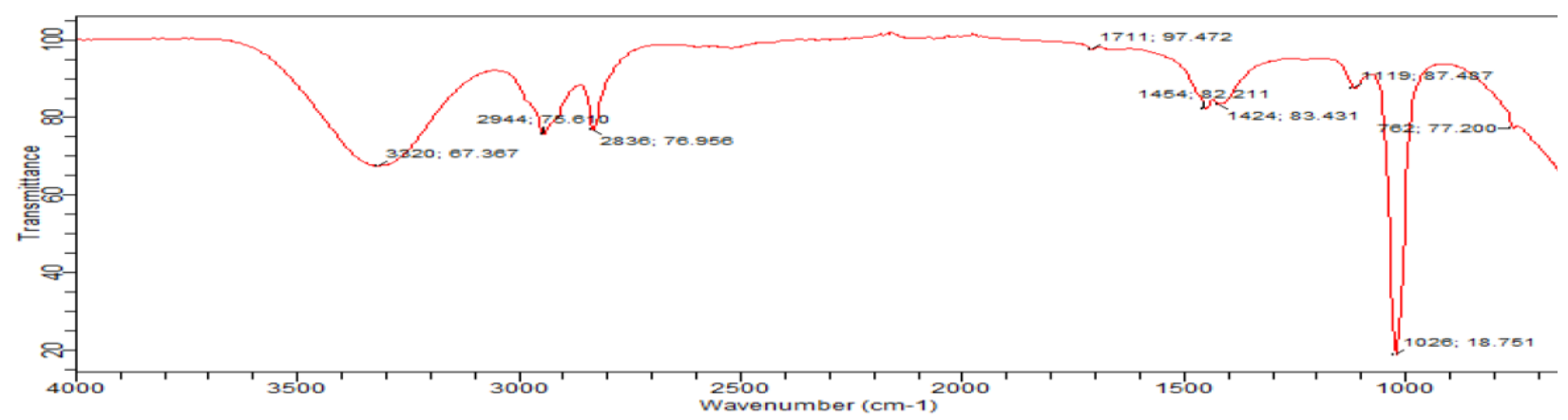

Fig5. FT-IR of Nymphae Pubescens leaf extract 
The peaks above are in the range of $500-3500 \mathrm{~cm}^{-1}$ indicating the presence of similar functional groups which have peaks at 762, 1026, 1711 and $3320\left(\mathrm{~cm}^{-1}\right)$.

These peaks show the presence of $-\mathrm{C}-\mathrm{O}$ stretching, $-\mathrm{C}-\mathrm{O}$ stretching, $-\mathrm{C}=\mathrm{O}$ stretching and $-\mathrm{OH}$ respectively.

The FT-IR spectrum of NLE is similar to the FT-IR of NLE film on the mild steel surface indicating the presence of similar functional groups. A similar situation was reported by Ngobiri, et.al. 2016.

\subsection{Surface Morphology Studies}

Surface morphology of mild steel specimens in uninhibited and inhibited seawater solution was carried out by immersion in a test solution after 24 hours at 303K. Figures 5 (a) and (b) shows the SEM images of the mild steel in the absence and presence of the inhibitor. A severely corroded surface morphology was observed after the immersion in the uninhibited system due to the corrosive attack by seawater. Corrosion was relatively uniform with no trace of a local attack. With addition of NLE, the corrosion damage was visibly reduced.

(a) $\mathrm{SW}+\mathrm{MS}$

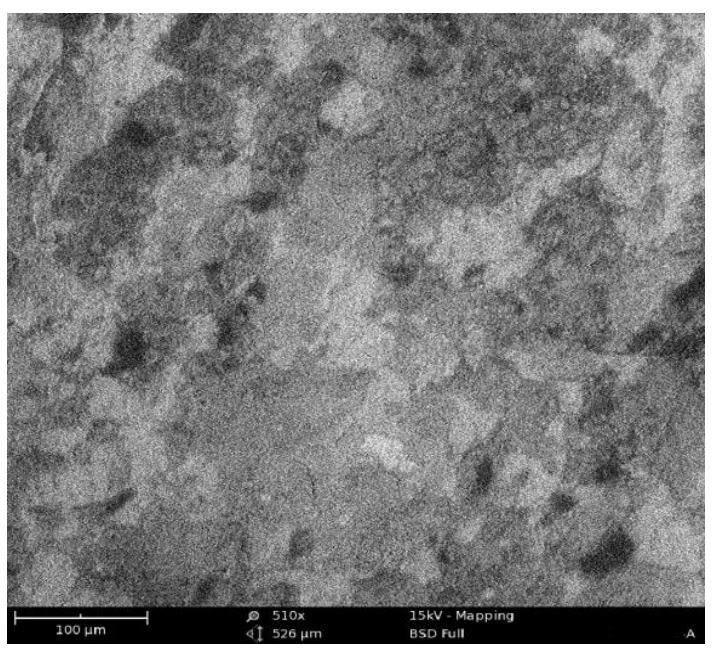

(b) $\mathrm{SW}+\mathrm{MS}+\mathrm{NLE}$

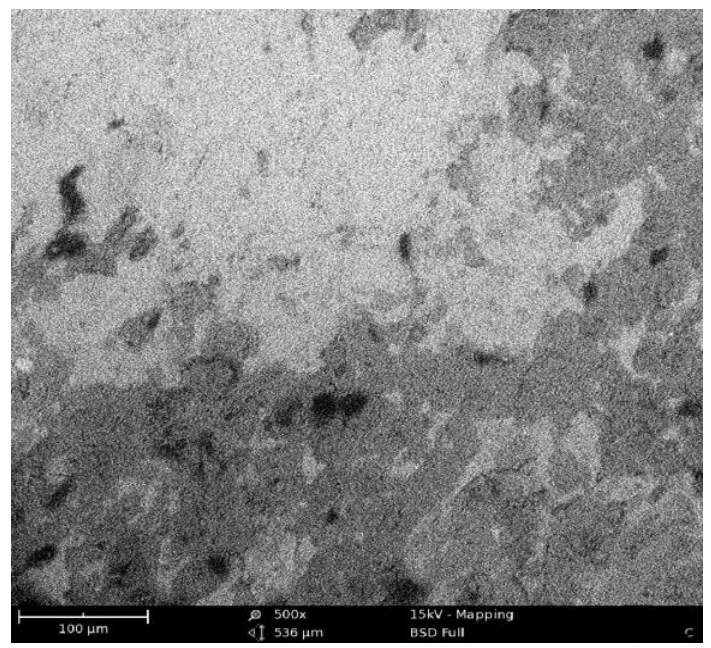

Fig6. Showing SEM micrographs of mild steel corrosion in uninhibited and inhibited seawater

\section{CONCLUSION}

NLE was found to inhibit corrosion of mild steel in seawater and the inhibition efficiency increased with increasing extract concentration. At the highest extract concentration of $5 \mathrm{v} / \mathrm{v} \%$, the optimum inhibition efficiency of $85.91 \%$ was attained. Although corrosion rate increased as temperature increased with subsequent decrease in inhibition efficiency, NLE is found to have inhibition efficiency of $77.36 \%$ even at $333 \mathrm{~K}$, the highest temperature studied... The lowest and highest corrosion rate were $0.31 \mathrm{mmp} \mathrm{y}^{-1}(1 \mathrm{v} / \mathrm{v} \%)$ and $0.07 \mathrm{mmp} \mathrm{y}^{-1}(5 \mathrm{v} / \mathrm{v} \%)$ respectively at $303 \mathrm{~K}$ and 0.41 $\mathrm{mmp} \mathrm{y}^{-1}(1 \mathrm{v} / \mathrm{v} \%)$ and $0.24 \mathrm{mmp}^{-1}(5 \mathrm{v} / \mathrm{v} \%)$ respectively at $333 \mathrm{~K}$. While the highest inhibition efficiency of $85.91 \%$ and the least inhibition efficiency of $24.51 \%$ was at $303 \mathrm{~K}$ and $333 \mathrm{~K}$ respectively when $(1 \mathrm{v} / \mathrm{v} \%)$ NLE was used. The inhibitor is an adsorptive inhibitor and its adsorption obeys the Temkin's adsorption isotherm. Thermodynamic data calculated and SEM micrographs from uninhihibited and inhibited system are also suggestive of adsorption of the inhibitor molecules on the mild steel surface.

\section{REFERENCES}

Abiola OK, Oforka NC, Ebenso EE and Nwinuka NM (2007). Eco - friendly corrosion inhibitors: Inhibitive action of Delonix regia extract for the corrosion of aluminium in acidic medium. Anti-Corrosion Methods Mater. 54(4): 219 - 224.

Adams S.M, Yaro S.A, Abdulwahab.M, Umaru.O.B (2015). Corrosion inhibition study of AldCu-Ni alloy in simulated seawater environment, Nigerian journal of technological development, 12, (1): 6-11. 
Aisha H. Al-Moubaraki1,Awatif Al-Judaibi, Maryam Asiri1(2015): Corrosion of C-Steel in the Red Sea: Effect of Immersion Time and Inhibitor Concentration. Int. J. Electrochem. Sci., 10: 4252 - 4278

Al-Otaibi M.S, Al-Mayouf A.M, Khan.M, Mousa A.A, Al-Mazora S.A, Alkhathlan H.Z. (2012).Corrosion inhibitory action of some plant extracts on the corrosion of mild steel in acidic media. Arabian journal of chemistry, 7: 340-346.

Ambrish, S.V,Singh.K and Quaraishi.M.A. (2010). Aqueous Extracts of Kalmegh (Andrographis paniculata) leaves as green inhibitors for mild steel in Hydrochloric acid solution. International Journal of Corrosion. Article ID: 275983, pp.1-11

Aramide, F.O.(2009). Corrosion Inhibition of AISI/SAE Steel in a Marine Environment. Leonardo Journal of Sciences. 5(15), pp. 47-52

Axelrod Glen S. (2005). A process for the preparation of natural salt formulations for seawater substitution, mineral fortification. Publication no: WO2013098857 A1, pp.1-3

Bammou.L, Belkhaouda. M , R. Salghi , O. Benali, A. Zarrouk H. Zarrok , B. Hammouti (2014). Corrosion inhibition of steel in sulfuric acidic solution by the Chenopodium Ambrosioides Extracts. Journal of the Association of Arab Universities for Basic and Applied Sciences ; 16: 83-90

Bardal.E (2004): Corrosion and Protection: Engineering Materials and Processes, Springer, London Limited, ISBN-1852337583

Eltre A.Y.(2007). Inhibition of Acid Corrosion of Carbon Steel using Aqueous Extract of Olive Oil Leaves. J,Colloid Interface Sci.,3(4),pp.578-583

Encyclopedia Britannica. Inc (2017). Water lily, https://www.britannica.com/plant/water-lily.

Hamdy.A and Nour Sh. El-Gendy (2013). Thermodynamic, adsorption and electrochemical studies for corrosion inhibition of carbon steel by henna extract in acid medium. Journal of Petroleum Environ Biotechnology; 22(1), pp.17:25

James A.O, Akaranta.O. (2009).Studies on the corrosion inhibition of acetone extract of red onion skin for mild steel in hydrochloric and sulphuric acid solutions.Sciental Africana.8, 1: 23-34

Kalada Hart and A.O. James (2014). The Inhibitive Effect of Aloe Vera Barbadensis Gel on Copper in Hydrochloric Acid Medium. Journal of Emerging Trends in Engineering and Applied Sciences (JETEAS) 5, 1: 24-29

Kester, D. R., Duedall, I. W., Connors, D. N. and Pytkowicz, R. M. (1967). Preparation of Artificial Seawater. Limnology \& Oceanography 12, 176-179.

Khaled,K.F.,(2008). Molecular simulation, quantum chemical calculations and electrochemical studies for the inhibition of mild steel by triazoles.Electrochim.Acta 53, 3484-3492

Malik A.U, Ahmad.S and Andijani.I (1995). Corrosion behavior of steel in Gulf Seawater Environment. Journal of Corrosion Science, 3 (7), pp.1521-1535

Melchers, R.E and Jeffery. (2005). The effect of corrosion on the structural reliability of steel offshore structures.Corros. Sci., 47(10). pp: 2391-2410

Mohan V.R., Nishanthini.,A .(2012). Antioxidant activites of Xanthosoma sagittifolium Schott using various in vitro assay models. Asian Pacific Journal of Tropical Biomedicine. 2, 3, Supplement : 1701-1706

Möller. H., Boshoff, E.T and Froneman, H. (2006).The corrosion behaviour of a low carbon steel in natural and synthetic seawaters. Journal of The South African Institute of Mining and Metallurgy.vol 106, (referred paper), pp. 585-592

Nnabuk.O.E (2009). Inhibitive and adsorption properties of ethanol extract of Colocasio esculanta leaves for the corrosion of mild steel in $\mathrm{H}_{2} \mathrm{SO}_{4}$.Interational Journal of Physical Sciences, 4 : 165-171

Nnanna A.L, Owate. I.O and Oguzie.E.E (2014). Inhibition of Mild Steel Corrosion in HCl Solution by Pentaclethra macrophylla Bentham Extract. International Journal of Materials Engineering, 4, 5: 171-179.

Olawale, O., Adekunle, O.F., Adesoji, A.A and Sunday, O.A (2016). Corrosion Inhibition of Mild Steel in seawater using Jatropha Stem. Eftimie Murgu Resita Anul ; 23, 1: 1453-7397

Oloruntoba,D.T.(2013). Corrosion inhibition of water Hyacinth on 1014 steel in a chloride environment, CJAR; 2, 2: 6-16.Available online at http:www.cjar.com

Orubite.K.O, Oforka.N.C. (2004). Inhibition of the corrosion of mild steel in hydrochloric acid solutions by extracts of leaves of Nypa fruticans Wurmb. Material Letters ; 58: 1768-1772.

Rahmanto W.H., Gunawan, Rahmad N. (2002). Corrosion rate of copper and iron in seawater based on resistance measurement. Journal of Coastal Development ; 5: 67-74 
Rajendran, A. and Karthikeyan, C. (2012). The Inhibitive Effect of Extract of Flowers of Cassia Auriculata in 2 $\mathrm{M} \mathrm{HCl}$ on the Corrosion of Aluminium and Mild Steel. International Journal of Plant Research ; 2 ,1: 9-14

Subir.P and Ishita.K (2016).Corrosion inhibition of carbon steel in acidic environment by papaya seeds as green inhibitors. Journal of Bio- and Tribo corrosion: 2 (2), pp.2:6

Citation: H. Kalada.G et al., "Corrosion Inhibition of Mild Steel in Simulated Seawater by Nymphae Pubscens Leaf Extracts (NLE)", International Journal of Advanced Research in Chemical Science (IJARCS), vol. 4, no. 12, pp. 32-40, 2017. http://dx.doi.org/10.20431/2349-0403.0412004

Copyright: (C) 2017 Authors. This is an open-access article distributed under the terms of the Creative Commons Attribution License, which permits unrestricted use, distribution, and reproduction in any medium, provided the original author and source are credited. 